\title{
EDITORIAL
}

\section{New Challenges for Transnational Environmental Law: Brexit and Beyond}

\section{INTRODUCTION}

This seventh volume of Transnational Environmental Law arrives at a most unusual moment for environmental initiatives worldwide. On the one hand, popular support for environmental care seems strong and stable: substantial constituencies and forceful interest groups have lined up behind efforts to combat the causes and effects of climate change, and many among the world's political, social, and commercial leaders stand firmly, if not altogether enthusiastically, in support of various forms of environmental protection. On the other hand, however, one finds more ominous developments. Bombastic anti-regulatory rhetoric from President Trump, and the surprisingly voracious appetite for such talk, signal not only headwinds for new initiatives but retrenchment for existing ones.

Deep social and political divisions are nothing new, but when aggravated they raise numerous issues worthy of scholarly inquiry. This issue of TEL features a number of articles that bear on, or even directly confront, the volatile legal environment portended by current events. A symposium gathers three articles that address the wave of rights-based litigation that challenges present understandings of background state liability for environmental protection in the context of climate change. Next, in an article sure to invite a great deal of discussion and response, Chris Hilson lays out the possible consequences for environmental law of the United Kingdom (UK) leaving the European Union (EU), often referred to as 'Brexit'. ${ }^{1}$ Other articles address the climate regime and ongoing efforts to promote cooperation and efficacy in the management and protection of international fisheries. As always, these articles do much to advance TEL's mission of encouraging and presenting interdisciplinary research about the role of law, and especially law beyond the state, in confronting contemporary environmental problems.

\section{HUMAN RIGHTS AND CLIMATE CHANGE}

The language of human rights has long given voice and vigour to momentous social movements. As an instrument of governance or social change, human rights law can hold enormous power, especially insofar as it resonates with widely held moral understandings. Standing alone, it also has important limitations. Just as the success

1 C. Hilson, 'The Impact of Brexit on the Environment: Exploring the Dynamics of a Complex Relationship’ (2018) 7(1) Transnational Environmental Law, pp. 89-113. 
of rights-based movements depends on shared public sensibilities, the efficacy of rights-based litigation depends on receptivity within the relevant tribunals.

This issue's Symposium collection sheds light on the role that human rights law could play in advancing global climate change policy in the era of the Paris Agreement. ${ }^{2}$ As Sam Adelman and Bridget Lewis explain in their Symposium Foreword, the contributors to this Symposium are by no means unaware of the headwinds that confront rightsbased litigation. ${ }^{3}$ Both Adelman and Lewis, in their individual contributions, bemoan the deficiencies of the Paris Agreement, noting the absence of clear legal footholds by which advocates could advance rights-based arguments. Lewis, however, identifies certain legal strategies that could yet bear fruit, arguing that the Agreement should be read to promote intergenerational equity. ${ }^{4}$ The rights of future generations, though backgrounded within the Agreement, are lurking just beneath the text, implicit in its references to sustainability and to climate justice. In Lewis' view, a generous reading, and a reading consonant with human rights theory, would require signatories to consider future generations in the context of states' existing human rights obligations.

Adelman is decidedly less optimistic. ${ }^{5}$ His analysis focuses on the rights of those populations, such as forest dwellers and island inhabitants, who are or will be most vulnerable to the effects of climate change. Although several articles of the Paris Agreement would appear to offer some hope for vulnerable populations, Adelman concludes that the Agreement's apparent forms of protection may well be ineffectual. In Adelman's view, the Paris articles on REDD+ and loss and damage could have been meaningfully strengthened by the inclusion of specific reference to the human rights of vulnerable groups. Absent any such reference, these articles could become relatively dead letters, especially as regards the rights of indigenous communities.

In the remaining Symposium contribution, Jacqueline Peel and Hari Osofsky offer a birds-eye view of rights-based litigation strategies around the world. ${ }^{6}$ These strategies are at an early stage of their development, and precious few suits have advanced beyond the preliminary stages. Cases such as the landmark Urgenda litigation in the Netherlands, ${ }^{7}$ analyzed previously in this journal, ${ }^{8}$ signify a growing receptivity to the application of human rights concepts to the context of climate change. The Juliana case in

2 Paris (France), 12 Dec. 2015, in force 4 Nov. 2016, available at: http://unfccc.int/paris_agreement/ items/9485.php.

3 S. Adelman \& B. Lewis, 'Rights-Based Approaches to Climate Change' (2018) 7(1) Transnational Environmental Law, pp. 9-15.

4 B. Lewis, 'The Rights of Future Generations within the Post-Paris Climate Regime' (2018) 7(1) Transnational Environmental Law, pp. 69-87.

5 S. Adelman, 'Human Rights in the Paris Agreement: Too Little, Too Late?' (2018) 7(1) Transnational Environmental Law, pp. 17-36.

6 J. Peel \& H.M. Osofsky, 'A Rights Turn in Climate Change Litigation?' (2018) 7(1) Transnational Environmental Law, pp. 37-67.

7 Stichting Urgenda v. Government of the Netherlands (Ministry of Infrastructure and the Environment), ECLI:NL:RBDHA:2015:7145, Rechtbank Den Haag, C/09/456689/HA ZA 13-1396.

8 J. van Zeben, 'Establishing a Governmental Duty of Care for Climate Change Mitigation: Will Urgenda Turn the Tide?' (2015) 4(2) Transnational Environmental Law, pp. 339-57; and P. Galvão Ferreira, " "Common But Differentiated Responsibilities" in the National Courts: Lessons from Urgenda v. The Netherlands' (2016) 5(2) Transnational Environmental Law, pp. 329-51. 
Oregon (United States (US)) $)^{9}$ also suggests a certain promise for rights-based strategies. At the end of the day, however, Peel and Osofsky, too, recognize that litigation premised on human rights is unlikely to deliver formal and substantive redress. Ultimately, the benefit and value of such approaches may lie in their visibility, for such cases do tend to bring public attention to climate change and to humanize the issue for distant audiences.

\section{BREXIT AND ENVIRONMENTAL LAW}

Along with the election of President Donald Trump in the US in late 2016, Brexit surely stands as one of the most salient geopolitical developments in recent years. Not only did the Brexit vote come as a surprise to the political commentariat, it also has opened a Pandora's Box of issues and concerns on various matters of law, economics, and policy. Environmental analysts have begun to unravel the many twisted threads that constitute the UK-EU regulatory relationship, attempting to discern how Brexit will affect environmental law in the coming years.

To that end, Chris Hilson has produced for this issue a crisp and comprehensive examination of the environmental implications of the UK's departure from the EU. ${ }^{10}$ Hilson's approach leaves no stone unturned. He avoids simplistic generalizations and offers instead a complicated and dynamic picture, noting throughout the article the hazards of positing causal connections within the UK-EU relationship. Impact and influence within that relationship, Hilson urges, are 'bi-directional and bi-dimensional ${ }^{11}$ and change over time. The article begins with a provocative twoby-two matrix: a ledger of sorts, listing both the positive and negative environmental policy impacts of the UK's membership of the EU, as regards both UK and EU policy. ${ }^{12}$ Readers who have been frustrated by black-and-white reductionist accounts, streaming unabated from distant quarters of the internet, will immediately appreciate the objectivity of Hilson's account, for it takes as its starting point the recognition that certain environmental policies emanating from both Westminster and Brussels may have actually been weakened by UK membership of the EU. Just as the UK's relative warmth towards biofuels cooled somewhat as a result of EU pushback, so also did the UK's pressure on matters from fracking to energy efficiency dilute what might otherwise have been more stringent policies in the EU.

Roughly the first two-thirds of Hilson's article winds its way through the likely practical consequences of Brexit in terms of both policy and outcomes. Certain conclusions may be drawn with some degree of confidence: any enforcement efforts premised on EU Member States' reporting obligations, for example, seem likely to be imperilled by Brexit. ${ }^{13}$ Much depends, of course, on a structural end point, which remains very much in doubt. One may accept or reject the 'soft'/'hard' Brexit dichotomy, but it surely conveys well the fact that crucial details of post-Brexit

\footnotetext{
9 Juliana v. United States, No. 6:15-cv-01517, (D. Or., 10 Nov. 2016) (Aiken, J.), 46 ELR 20175.

10 Hilson, n. 1 above.

11 Ibid., p. 91.

12 Ibid., Table 1.

13 Ibid., pp. 102-3.
} 
relations are in flux. 'The eventual model chosen for the UK's future relationship with the EU,' notes Hilson, 'is likely to make a significant difference to whether Brexit turns out to be positive or negative for the environment'. ${ }^{14}$ Even beyond matters of formal structure, trade relations between the EU and UK will undoubtedly, given their magnitude, influence policy on both sides of the Channel. UK manufacturers, for example, in all likelihood will choose to comply with environmental product standards rather than opt out of the massive EU market.

Perhaps the most insightful elements of Hilson's analysis come towards its end, where he reflects more abstractly on sovereignty, on devolution, and especially on the environmental implications of the principle of subsidiarity - an idea very near to Brexit's nerve centre. One of the lurking difficulties (if not contradictions) beneath the 'leave' position was always the question of how much devolution was enough, as well as the corresponding recognition that decentralizing forces, once unleashed, cannot so easily be contained. Some of the loudest advocates for 'leave' now find themselves lacking credibility as they assert the need for policy centralization in Westminster. Where certain Welsh and Scottish voices may be quite keen to echo the devolutionary chorus, numerous others who sought the repatriation of EU competencies will now need to reprise the same justifications for supranational governance that were deployed against them barely a year ago.

Hilson's contribution to this mess is subtle and wise, perhaps even shrewd. Hilson carefully articulates several justifications, rooted in subsidiarity, for policy centralization in the environmental sphere. Even those who press most resolutely for policy formation at the periphery acknowledge that political identity and self-governance require some forms of centralization or cooperation under certain conditions. The elimination and prevention of some barriers to trade, for example, promotes rather than degrades subsidiarity. Some of these justifications link directly to important matters of local environmental well-being: problems related to transboundary air pollution, cross-border rivers, and wildlife migration, to select a few of Hilson's many examples, all would appear to require a healthy dose of coordination if not outright pooling of sovereignty or regulatory competence. Although any preserved, renewed, or yet-to-be-established modes of transnational environmental cooperation may look quite different from those in pre-Brexit Europe, the forces behind them may suggest that Brexit's environmental effects will be far more complicated than described on the evening news.

\section{REFRAMING THE LAW OF CLIMATE CHANGE}

Benoit Mayer has devoted a good deal of intellectual energy in recent years to the task of elaborating the nature of states' duties with regard to climate change under general international law. ${ }^{15}$ In his submission to this issue

14 Ibid., p. 97.

15 B. Mayer, 'State Responsibility and Climate Change Governance: A Light through the Storm' (2014) 13(3) Chinese Journal of International Law, pp. 539-75; B. Mayer, 'The Applicability of the Principle of Prevention to Climate Change: A Response to Zahar' (2015) 5(1) Climate Law, pp. 1-24; B. Mayer, 'Climate Change Reparations and the Law and Practice of State Responsibility' (2016) 7(1) Asian 
of $T E L^{16}$ Mayer takes up an important question raised by his line of inquiry: if general international law entails duties to mitigate and make reparations for climate change, then how should the international community understand the intricate body of climate change law established pursuant to the United Nations Framework Convention on Climate Change (UNFCCC) ${ }^{17}$

The question is as timely as it is important. Despite recalcitrance from the US, efforts to understand and implement the letter and spirit of the Paris Agreement are well under way worldwide. Paris, and the legal edifice beneath and before it, could be understood to liquidate and thus supersede state responsibilities under general international law. Mayer resists this conclusion. General norms such as the no-harm principle and the law of state responsibility, including obligations to abate and make amends for international harm caused by wrongful state contributions to global emissions, are in Mayer's view logically and legally prior to the entire climate change regime. Moreover, the sum of international action towards mitigation and adaptation 'stop short of fulfilling the obligations of states under general international law' ${ }^{18}$ Climate change law would only preclude the application of general international law if the two stood in conflict, and Mayer is at pains to establish that no such conflict exists. Neither, he argues, is it legally correct (let alone required) to understand climate law as a more specific (and therefore pre-emptive) application of general norms, for the climate change regime presently remains 'confined to much less ambitious obligations' ${ }^{19}$ The paltry international support for climate change adaptation, for example, cannot possibly amount to a fulfilment of developed states' remedial obligations under Mayer's conception of general norms of international law. ${ }^{20}$

However, if the climate change regime is neither a replacement for nor an elaboration of state duties under general international law, what is it? Mayer posits that this regime can best be understood as a compliance regime: 'a set of steps to gradually overcome political obstacles to compliance with general international law in relation to climate change', ${ }^{21}$ akin to those series of agreements devoted to the development of international humanitarian law or the phasing out of ozone-depleting substances. ${ }^{22}$ For Mayer, a compliance regime is one erected in order to address 'gaps' in compliance, which in this instance amount to gaps in emissions controls and reparations, in turn caused by gaps in global ambition, national commitment, and state action. ${ }^{23}$ Having established this analytical scaffold, Mayer then analyzes

Journal of International Law, pp. 185-216; and B. Mayer, 'Less-Than-Full Reparation in International Law' (2016) 56(3-4) Indian Journal of International Law, pp. 463-502.

16 B. Mayer, 'Construing International Climate Change Law as a Compliance Regime' (2018) 7(1) Transnational Environmental Law, pp. 115-37.

17 New York, NY (US), 9 May 1992, in force 21 Mar. 1994, available at: https://unfccc.int/resource/docs/ convkp/conveng.pdf.

18 Mayer, n. 16 above, p. 124.

19 Ibid., p. 127.

20 Ibid., pp. 124-125, 131-4.

21 Ibid., p. 127.

22 Ibid., pp. 118-9, in particular nn. 19-20.

23 Ibid., pp. 127-8. 
elements of the climate regime in terms of their tendency to diminish or exacerbate aspects of the compliance gaps. The shift from a top-down to a bottom-up emissions control regime, for example, may be regarded as an improvement in the global ambition gap, but its failure to require quantified emissions reductions from the Carbon Majors only augments the gap in national commitment. ${ }^{24}$ Ultimately, Mayer regards the climate regime as an attempt to enhance compliance through 'international socialization' rather than through the classical remedial devices afforded by international law. ${ }^{25}$

\section{TOWARDS LEGAL AND SUSTAINABLE FISHERIES}

This issue of TEL is rounded out by a pair of articles analyzing international fisheries. The submission by Barış Soyer, George Leloudas and Dana Miller takes on the enduring challenge posed by illegal, unreported, and unregulated (IUU) fishing. ${ }^{26}$ The authors posit a novel approach to an old concern: to the extent that vessels engaged in IUU fishing need and obtain liability insurance, why not restrict access to such insurance as a means of deterring illegal fishing operations?

An intervention of this sort raises a host of questions. Firstly, one might wonder why and whether vessels engaged in IUU fishing would bother to obtain insurance. The latter question is not so difficult to answer as it might first appear: via an empirical study of searchable databases provided by insurance providers, the authors were able to learn, stunningly, that nearly half of the large vessels officially listed or suspected of IUU fishing activities (by INTERPOL, the EU, and other international fisheries organizations) had secured liability insurance from these providers. ${ }^{27}$ Insurance cover, it would appear, is an expense not spared even by vessels otherwise in violation of international law.

The question of why such vessels obtain insurance is less tractable. Reviewing the underwriting practices and coverage of major marine liability insurers, the authors find that these insurers provide no coverage for losses arising from involvement in illegal activities. ${ }^{28}$ This finding, combined with the ever-present incentive of insurance firms to reject claims, would seem to suggest that vessels conducting IUU operations are paying for coverage for which 'the prospects of recovery ... are bleak'. ${ }^{29}$ To be sure, insurance firms are no doubt all too eager to supply coverage to entities to whom pay-out is unlikely; these firms not only lack an organic incentive to deny coverage, but perhaps have a ready incentive to provide it. Soyer and his co-authors conclude that insurance is procured not to protect against actual loss, but rather to acquire the licence to operate required by the relevant port authorities. ${ }^{30}$ If this is the

24 Ibid., pp. 130-1.

25 Ibid., p. 134.

26 B. Soyer, G. Leloudas \& D. Miller 'Tackling IUU Fishing: Developing a Holistic Legal Response' (2018) 7(1) Transnational Environmental Law, pp. 139-163.

27 Ibid., p. 144.

28 Ibid., pp. 145-8.

29 Ibid., p. 148.

30 Ibid., p. 149. 
state of affairs, then liability insurers have been inadvertently and perhaps unwittingly roped into an assistive and enabling role with respect to IUU fishing.

Given that an economic intervention could go some distance towards deterring illegal fishing, the authors ponder avenues by which the provision of liability insurance could be incorporated into the international law enforcement and deterrence regime. They evaluate first the question of whether existing regulations could be read to prohibit the provision of insurance to IUU vessels. Finding that such a reading is 'tenuous at best', 31 they instead stake their argument on proposed amendments to EU and UK rules on IUU fishing. ${ }^{32}$ Political opposition from insurance providers notwithstanding, the authors conclude that effective amendments could be written and implemented with relative ease, and would provide one more weapon in the arsenal against IUU fishing.

Legal efforts to combat illegal fishing represent one approach towards preserving and improving global fisheries; fishery certification initiatives are another. Since its initial adoption in 1998, the Marine Stewardship Council Fisheries Standard and Guidance (MSC FSG) ${ }^{33}$ has emerged as the most prominent among private fisheries certification standards. Markos Karavias uses the FSG as an opportunity to analyze the relationship between private, 'new governance'-style certification processes and old-style international law. ${ }^{34}$

Karavias' article begins by noting the unusual space occupied by private standards in the international legal sphere: though some regard such standards as evidence of the declining influence of formal international law, others see instead a symbiotic relationship between international law and influential private organizations. Karavias is decidedly in the latter camp. The bulk of his article amounts to a careful description of the interaction (used here as an analytical term of $\mathrm{art}^{35}$ ) between the FSG and, in particular, the Code of Conduct for Responsible Fisheries (CCRF), promulgated by the Food and Agriculture Organization (FAO) of the United Nations. ${ }^{36}$ Karavias plots the development of the FSG against the CCRF, noting as well the frequent and explicit incorporation of international legal standards into the voluntary FSG. However, the influence does not run in only one direction. In the years following the adoption of the FSG, not only the FAO but also domestic authorities looked to the FSG in order to establish plans of action for the elaboration of legal standards. The Maldives, for example, adopted harvest control rules derived from the FSG for the purpose of 'maintaining MSC certification' ${ }^{37}$

The extensive and intricate interaction between private and public international action in this case study suggests to Karavias an affirmation and amplification of 'the

31 Ibid., p. 158.

32 Ibid., pp. 160-1.

33 MSC FSG, Version 2.0, 1 Oct. 2014, available at: https://www.msc.org/documents/scheme-documents/ fisheries-certification-scheme-documents/fisheries-standard-version-2.0.

34 M. Karavias, 'Interactions between International Law and Private Fisheries Certification' (2018) 7(1) Transnational Environmental Law, pp. 165-84.

35 Ibid., pp. 171-3.

36 AO Doc. C95/20 (Rev.1), 29 Sept. 1995, available at: http:/www.fao.org/docrep/005/v9878e/ v9878e00.htm.

37 Karavias, n. 34 above, p. 179. 
centrality of international law with regard to the task of fisheries management' ${ }^{38}$ At the same time, careful and credible efforts towards private certification acquire a form of legitimacy through interaction with international law, which in turn can bolster the international standing and efficacy of private, cooperative governance initiatives. The exploration of this complex dynamic offers a powerful illustration, in terms more eloquent than any definition could, of the extent to which the adoption of a transnational perspective enriches our understanding of environmental law in contemporary societies.

Editors-in-Chief

Thijs Etty

Veerle Heyvaert

Editors

Cinnamon Carlarne

Dan Farber

Bruce Huber

Josephine van Zeben

38 Ibid., p. 180. 